\title{
An Analysis of Nation Brand Attractiveness: Evidence from Brand Zimbabwe
}

\author{
Cleven Masango, Vannie Naidoo \\ University of KwaZulu Natal, Westville Campus, Durban, South Africa \\ cmasango@cclint.net,215076580@stu.ukzn.ac.za, Naidoova@ukzn.ac.za
}

\begin{abstract}
This paper examines the attractiveness of Brand Zimbabwe based on the factors perceived to impact on national competitiveness. Nation brand attractiveness is a necessary condition for a country to achieve influence and to effectively compete for global resources. Countries can enhance their attractiveness by building on their national brand equity and dealing with negatives around the national brands. The research sought to determine the perception towards Zimbabwe's global risk and competitiveness; to ascertain the variables that promote competitiveness for Brand Zimbabwe and to contribute to the literature on risk perception and its impact on behaviour towards nation brands. The study followed a mixed approach; a combination of interpretivism and positivism. The research drew 372 respondents from politicians, scholars, the media, civic organisations, government officials, church and international organisations. The research established that Brand Zimbabwe faces glaring threats risks that impact on the country's international image. The brand is affected by politics and governance together with socio-economic factors. Management and control of nation brand perception are critical for nations to distinguish themselves and to create vantage positions for sustainable performance. The way a country is viewed internationally is a function of how the country deals with factors that threaten its global competitiveness and perception towards the nation brand. Zimbabwe's quest for foreign direct investment, international visitation and export revenue requires that the country deals with its nation brand image.
\end{abstract}

Keywords: Nation branding, competitive, risk, attractiveness, differentiation

\section{Introduction}

Zimbabwe has gone through a corrosive period spanning nearly two decades during which the country's once celebrated reputation and image lost significant equity. The period saw the country experience deteriorating quality of life and global attractiveness. The country disengaged from the international community and endured economic and political isolation. The diplomatic fall-out between Zimbabwe and the United Kingdom was due to Zimbabwe's efforts to promote equitable and distribution and ownership of the economic factors including land. A major inflection point in the history of the brand is the fall of the former President R.G. Mugabe's administration in November 2017 and the entry of President E.D. Mnangagwa. This marked a major opportunity for turning around the fortunes of the national brand. The former Senior Principal Director in the Office of the President and Cabinet, Ambassador Mary Mubi said that the country needed to develop a global campaign that informs the world that Zimbabwe is a viable nation with working institutions, tremendous opportunities in all sectors, vibrant culture and great places to visit and with a peaceful, resilient people and the most literate workforce in Africa. Branding Zimbabwe could be such a daunting task given the negative Brand association suffered by Zimbabwe given its subsequent comparison with such ill-reputed countries as Burma, Iraq, South Sudan, Cuba, Belarus and North Korea (Gumpo, 2005). It is also advised that being proactive in rebranding and repositioning goes beyond communication and doing cosmetic work to a complete and integrated reconfiguration of the brand (Gilmore, 2002).

Problem Statement and Objectives of the Study: It has been noted that it is not sustainable for Zimbabwe's nation brand to continue existing in its current form. The nation brand has lost so much attraction and equity due to perennial political, social and economic challenges faced by the country. Nation branding activity should deal with the mind and perception of consumers to influence their behaviour towards the national brand. Perception of risk can be such a significant driver of consumer buying behaviour. Consumers define their own reality through perception. This research thus attempts to unpack the risk profile of Brand Zimbabwe (as perceived by the respondents) to inform the reconfiguration of the national brand. This study set out to achieve the following objectives: 
- To determine the perception towards the country's global risk and competitiveness.

- To ascertain the variables that promote competitiveness for Brand Zimbabwe.

- To contribute to the literature on risk perception and its impact on behaviour towards nation brands.

Hypothesis 1: Zimbabwe is not a competitive country based on identified competitiveness and differentiating indicators

Hypothesis 2: Zimbabwe is a high-risk country based on social, economic, environmental, geopolitical, and technological factors.

\section{Literature Review}

Nation branding is a concept that stems from marketing (Ih-Prost \& Bondaz, 2014). It is defined as the way in which a country influences how it is perceived by foreigners, particularly in the context of positive opinion at the evocation of the said nation (Anholt, 2010). Nation branding has become a global phenomenon that requires countries to take control of their brand identities to overcome international economic, social, cultural, and political competition (Tecmen, 2018). Many countries, including the United States, France, United Kingdom, Spain, Japan, China, South Korea, Singapore, South Africa and Israel have accepted and practiced nation branding (Anholt, 2010).

Purpose of Nation Branding: The overall aim of nation branding is to produce a differentiated image which can drum up attention to competitiveness and comparative advantages of the nation. As eluded earlier, nation branding discourse borders on boosting export performance, mobilisation of foreign direct investment, drawing talent, elevation of tourist activity (Zeineddine, 2017). Positive brand equity is expected to marshal real commercial, social, and political returns for a country (Dinnie, et al., 2010). Additionally, when a nation holds positive brand equity, it wields capacity and strength to combat foreign threats, since powerful brands can safeguard the nation from negative publicity (Dinnie, 2015). Nation branding is viewed as a concept in sync with the escalating international competition and pressure facing nations equally in local and external spheres (De Chernatony, 2006). Nation branding is attracting a lot of interest from academics, professional consultants, governments and non-state actors (Bolin \& Miazhevich, 2018). The notion of nation branding is presented by branding experts as a strategic imperative useful to deal with the dynamics of geopolitics, international economics and the influence of international media.

Nations are getting more business-orientated in their socio-economic programming in response to pressure from global competition and increasing domestic socio-political sentiment (Alvarez \& Campo, 2014). Progressive nations realise the need to proactively manage and control their brand reputation to distinguish and enhance their attractiveness (Lee, 2009). The way a nation is viewed by other nations is a function of collective opinion about that country's attractiveness and their lived experiences of such a nation (Dinnie, 2015). It is believed that nation branding presents a platform to cultivate the attractiveness profile for a country (Konecnik \& Go, 2008) and (Lee, 2009). Each nation has its own identity, which if not prudently managed, potentially gets subjugated by (adverse) stereotype. Stereotypes are known to potentially impact a country's strategic objectives (Skinner \& Kubacki, 2007) and (Dinnie, 2008a). Nearly all countries face both positive and negative generalisations and stereotypes (Avraham, 2018). Notwithstanding the fact that stereotypes pose a serious barrier against tourism and investment, studies have been done to suggest possible nation brand repair strategies. Experts and researchers accept that brands evolve over time and at worst suffer damage from internal and external risk factors.

It remains the responsibility of the country to, at best, proactively deal with the threats before they manifest by influencing negative behaviour towards the brand. The author observes that international images of most nations are hounded by negative stereotype (ibid). Such emergent perceptions, however, and negative stereotypes can be corrected over time through conscious and coordinated nation branding activity (Dinnie, 2015). It usually takes some time to alter and correct the negative nation image, thus nations should adopt a long-range perspective, to attain conscious awareness and acceptance of desired national identity (Quelch \& Jocz, 2009). Only through concerted and long-term engagement can nations restore impaired nation brand images in targeted audiences, as quick short-gun publicity and public relations campaigns are of no 
consequence. The challenges around the 'Canada is back!' campaign highlighting the importance of dealing with the real issues affecting the nation brand rather than dwelling on propaganda (Nimijean, 2018). Nation branding strategy was not successful owing to basic challenges around political management and public administration under which brand threats were manifest. It is essential to focus more on doing than on communicating intentions in the face of real issues around the brand (Nimijean, 2018).

Therefore, it is paramount for nation branding strategy to go far beyond graphical identity to integrate broader facets such as national development strategy, consumer and stakeholder engagement, messaging harmonisation for internal and external audiences among others (Lee, 2009). Nation branding provides an opportunity to identify and articulate a country's competitive and comparative advantages as a value proposition to the world (Anholt, 2007a). Observers believe that destinations cannot overcome global competition simply on the basis of their comparative advantages embodied in the landscape, natural or human-made features because such advantages are found in other places (Bregoli, 2016). What remains essential is for nations to construct and align their brand image and reputation to support their long-term nation brand equity. Findings from a study on Haiti and the Dominican Republic confirm the positive nexus between a country's level of stability and tourism (Anglade, 2018). The study also affirmed that the level and quality of infrastructure influences a country's reputation and global competitiveness.

Attentive nation brand positioning affords a nation a competitive position over others and successful repositioning can unlock great potential, in instances where a nation's image lags behind its reality (Reibstein, 2017). Nations are attempting to create and portray meaningful differentiation ahead of their counterparties. It has been emphasised that nation branding be taken as long-term undertakings done beyond paying lip service to issues facing the country. Caution should be taken against the incidence of the 'Dallas experiment' in which the then New Zealand Market Development Board inundated Dallas City with the New Zealand campaign. The campaign was run for a period and witnessed an exponential growth in export sales. A significant slump in sales was, however, experienced 12 months later after the campaign was terminated. As such, tactical short-term promotional exercises must not be seen as a substitute for strategic nation branding (De Chernatony, 2006). Nation branding rides on truthfulness. One needs to have a good product to compete effectively. Good national policy is fundamental in dealing with nation branding challenge. The Winner is Georgia Campaign failed because of the facts on the ground conflicting with the new branding narrative (Dinnie, et al., 2010).

Nation branding effort has a tough time to overcome poor national policy and government behaviour. It has been noted that "just a good name on its own cannot make a brand" but a sustained building of marketleading brand capacities does (Abimbola, 2010). This, however, is more than a brand communications strategy. Legacy nation brands are advantaged compared to emerging nations because they enjoy established historical positive associations. Such destinations with legacies include America, Germany, Britain, Italy, France, London, New York, Munich, Rome, and Dubai among others. On the contrary, are also the little countries that people struggle to differentiate; thus, "who knows the difference between Kazakhstan, Pakistan, and other stains?" (Olins, 2013) there is no substitute for nation branding and as such it is a real issue that requires government attention. It has been observed that nation branding needs to be consciously pursued otherwise lack of a resolute drive to brand a nation invites image drift as other people do it on behalf of the government - albeit, for their selfish reasons (Wharton, 2016).

Strategic Implications of Nation Branding: There are a number of strategic implications of nation branding. Nations compete daily with the entire world and economic blocks for global resources, tourism, investment and export markets. In addition, it is observed that nations with unknown or poor reputation are marginalised perceptually and that their top of mind awareness levels is very low (Spio, et al., 2011). They, thus, do not feature in the minds of their global audience, which adversely influences their commercial success. In addition, the emphasis of public opinion and attitude towards another nation is gaining prominence in international economics and politics. Public diplomacy aims to define state activities and nonstate players whose role influences the sustenance and elevation of a nation's soft power (Kemming, 2009). The traditional diplomatic undertakings are certainly being complemented by the involvement of these other stakeholders in the modern global context. The new paradigm requires that public diplomatic efforts be cast beyond the purview of consulates, ambassadors, and departments of international affairs. Governments 
should facilitate some collaboration linking multiple actors outside the administrative realm across the business, academia, think tanks, non-governmental organisations (NGOs), media and political parties. Public diplomacy has leapt beyond traditional propaganda to generating strong advocacy to affect the public's psychosomatic and attitude forming processes. The reality of global dynamics remains that nation branding is applicable to countries as they seek to reposition themselves on the global market. There is a unanimous national consensus that the country's brand has lost significant equity over time. As for qualitative data set, thematic analysis was used where emerging themes were presented and analysed keeping with the research objectives.

Nation Branding Pressure: A country's image greatly influences and impacts on a nation's ability to promote its exports, visitation and attraction of global investments (Kapferer, 2008). Researchers have observed that low level of FDI inflows to Zimbabwe has been explained in the context of an underlying negative image faced by the country as an investment destination (Sikwila, 2015). Countries inexorably jostle for the limited FDI hence the need for nations to craft strategies to salvage a reasonable share of the global resources. Zimbabwe has performed badly against its regional counterparts over time according to the World Economic Forum report (Klaus, 2016). A positive nation brand image thus becomes an essential global negotiation instrument for all countries. Governments should ascertain the world's view on their countries and develop appropriate image management strategies (Anholt, 2007a), (Haig, 2005) and (Jaffe, 2015). It is the role of governments to proactively manage their country's reputation and image to meaningfully support their economic, political and social objectives. This huge task has become one of the primary preoccupations of modern governments and Zimbabwe is not an exception to this. Zimbabwe's nation brand has been under attack for nearly twenty years as the country's economy witnessed a serious slump, tourism performance plummeting, and also the general social welfare and standard of life reaching its lowest ebb since independence. Generally, the academics, businesspersons, tourism players, politicians, diplomats and the public agree that Zimbabwe should work on reclaiming its regional and global status.

\section{Research Methodology}

This study was thus based on a mixed approach methodology; a combination of interpretivism and positivism consistent with (Rolfe, 2006) and (Kato, 2002) who accept that methodological triangulation provides better results and a complete picture of social phenomena. Mixed methodology enhances the breadth and depth of the research as it combines measurement of the extent of occurrence with the explanations and narratives about phenomena. It can be argued that by combining both types of research, the limitations of each individual method can be offset and gaps of data can be filled or predicted especially perceptions, opinions, meanings, attitudes and beliefs. The research was based on a survey on stakeholders around brand Zimbabwe where a sample of 384 computed through the sample size statistical formula (Cochran, 1977). A total of 372 respondents however, participated in the survey. In this enquiry, an internal constancy method was employed to ascertain the consistency of the data collection tool. Computed results for the Cronbach's Alpha Coefficient for the instrument was 0.883. It drew respondents from politicians, scholars, the media, the civic organisations, the government, local community and traditional leadership, the church and international organisations. The study targeted adult respondents above 18 years given the complexity of the subject under study. The study consciously considered respondents who related with Brand Zimbabwe from a political, economic, social angle, or who could offer valuable opinions and insights based on their professional exposure. The sampling approach was consistent with the stakeholder theory given the multiple stakeholders who consume the national brand. The selection of respondents was based on competence, perspective and experience dimensions.

Data Collection: The research utilised questionnaires and in-depth interviews to collect primary data. A set of five-point Likert Scale type of questions was used to gather primary data from Brand Zimbabwe stakeholders whilst open-ended questions were used to collect data from key informants. A Likert Scale uses an ordinal psychometric measurement of views, attitudes, beliefs and opinions. Each question in the instrument was presented as a statement or claim where research subjects would show the extent of agreement or otherwise in a structured response type format. The Likert Scale questions were used because they are universally used for survey data collection and are easily understood by respondents. In-depth interviews were carried out with the aid of a depth interview guide. The interview guide carried a list of 
open-ended questions to allow key informants the leeway to freely and fully express themselves on issues under investigation. Participation was drawn from the public, government, business, and non-governmental institutions. The use of self-administered questionnaires together with personal interviews brought the advantages of triangulation to the research (Sudman, et al., 1965).

Data Analysis: Survey data was analysed using SPSS version 21. Frequency analysis was used to analyse questions asked using a five-point Likert Scale, and these were presented in a percentage format. In addition, factor analysis was used for hypotheses testing using a dimension reduction methodology. Verification of the hypothesis, for acceptance or rejection, made use of the null hypothesis based on the analysis of item loading factors of each variable. Factor Analysis remains applicable in social sciences to test hypothesis achieving this by measuring relationships between observed scores and latent scores of variables. The more correlated the variables are, the better (Schmitt \& Sass, 2011). Varimax rotation with Kaiser-normalisation was also employed, given that its cross-loadings were lower than the other factor matrix rotation. Correlation Matrix was employed to check multi-collinearity and the relationship between variables.

\section{Findings and Discussion}

Characteristics of Respondents: The respondents in this study were drawn from across nine sectors of the economy, the country, age groups; a reflection of views from people of diverse backgrounds. Respondents to the quantitative research were from Harare (70.2\%) followed by Bulawayo with 8.6\%, Mutare with 7.5\%, Masvingo (4.8\%) and then Gweru with 3.8\%. Bindura had 1.6\%, Diaspora had 1.6\%, Chinhoyi, and Hwange had $0.8 \%$ each and Kwekwe with the least number of respondents $(0.3 \%)$. More males participated in the research with a frequency of $222(59.7 \%)$ as compared to their female counterparts with a frequency of 150 (40.3\%). In terms of age, the age range 26 to 45 had the highest frequency of 238 (64\%) with the 45 to 55 range following with a frequency of $63(16.9 \%)$ then the 18 to 25 whose frequency was 58 (15.6\%). People who are more than 55years had the least frequency (13) with the percentage (3.5). In addition to the above, interviews were conducted with participants from government, industry, civil society and foreign investors and tourists. A total of 10 respondents were drawn from the Zimbabwe Investment Authority (ZIA), ZimTrade, Zimbabwe National Chamber of Commerce (ZNCC), from Ministry of Macroeconomic Planning and Investment Promotion, from Ministry of Industry and Commerce, from Ministry of Foreign Affairs, from the Office of the President and Cabinet (OPC), Ministry of Tourism and Hospitality, banking, development partners, civil society, the tourism and hospitality sector, academics and economists. The research also drew participation from 7 foreign tourists and investors.

Competitiveness and Differentiation: An assessment of the market perception of the competitiveness and differentiation of Brand Zimbabwe based on such factors as physical infrastructure, macroeconomic environment, health, education, and product and service market efficiency was part of the investigation. The respondents were required to express their view on Zimbabwe competitiveness based on a set of competitive and differentiating factors. The country viewed positively on natural resources and factor endowments (76\%); the country's geographical location (74.8\%); education and literacy levels (72.6\%); labour market efficiency (68.8\%); and skills profile (66\%). The factors were considered to give brand Zimbabwe some competitive and comparative advantages. Most respondents, however, concurred that Zimbabwe was weak and uncompetitive in terms of cost and ease of doing business (74.5\%); currency stability and volatility (74.1\%); macroeconomic environment (74\%); political uncertainty and instability (73.1\%); health services and systems (70.5\%); financial market efficiency (68.8\%); public institutions (68.5\%); physical infrastructure (66.4\%); factor prices (65.8\%); facilities and services (61\%); product and service market efficiency (57.5\%); and technology environment and adoption (55.1\%). There seems to be a heavy skew against the brand. Whilst the country could is viewed to be endowed with natural advantages, its administration and support environment impairs on the attractiveness of the country. The country's political and economic space management weighs heavily against the country.

The respondents concurred that Brand Zimbabwe presented a hostile environment for investors and visitors alike. They advised that the general perception held by foreigners particularly from the traditional source markets was that Zimbabwe was very risky, politically unstable and economically troubled. Some visitors to Zimbabwe however, advised that they changed their negative opinion on the country after visiting. The 
negative views on the country were formed after the government-sponsored agricultural reforms and the indigenisation and economic empowerment programmes. There were suggestions from the respondents that the country was a victim of 'unfair and detrimental' media (local and international) coverage that impaired investor perception and behaviour. Fair or not fair coverage, the country needs to do something to generate positive perception towards the brand. It is crucial to relate with the realities of life in branding bearing in mind that brand consumers make their purchase decisions based on their perception of the brand rather than the realities of the product (Anholt, 2007a), (Haig, 2005) and (Jaffe, 2015). The research findings from foreign interviews corroborate the findings from the local key informants that the country was viewed as a political hotbed with immature democracy where there was an abuse of resources and high poverty levels. There was an emphasis that Zimbabwe was once an attractive country and economy whose fate was ravaged by politics and poor governance to recede into a 'failed economy'.

The general sentiments that emerged from foreigners were of skepticism, negativity and at worst, utter dislike for the country. It was however also thought-provoking to note that whilst some viewed the country as a failed state, others highlighted Zimbabwe's natural beauty and heritage; hospitable people and a possible great future regional country. It was however, established that the negative image for Zimbabwe was not unique to that country. Most African countries suffered from negative reports on Africa escalated by developed countries that advance Eurocentric or American views on development. The nation branding discourse should therefore be approached from a Pan-African perspective. The research identified education as one of Zimbabwe's positive competitive factors with $52 \%$ of the respondents affirming whilst financial market efficiency was regarded negatively by $55 \%$ of the respondents. A factor price was also viewed negatively by $51 \%$ of the respondents. The research findings reflect the reality on the ground. Another big issue viewed negatively against the national brand was currency and the cash situation. Accordingly, the Reserve Bank of Zimbabwe (RBZ) commented that apart from the declining GDP and trade deficits, cash shortages were a major characteristic of the economy since 2015. Long queues for withdrawals in banking halls and at automated teller machines (ATMs) remained a permanent feature of the banking experience (RBZ, 2016). In May 2016, the RBZ introduced bond coins and notes to ease the cash shortages. The liquidity crisis signified a "dysfunctional multi-currency system" dominated by a strong United States Dollar. The US Dollar substituted all other currencies in the Zimbabwe's multi-currency basket, making the country a high cost producing country and an expensive tourist destination (RBZ, 2016).

This is particularly so given the uncoordinated approach to nation branding predominantly driven to advance the tourism destination brand. A country brand has an influence on its tourism, exports, governance, investment and unification of people and cultures (Kalamova \& Konrad, 2010). It is also advised that national prosperity is not inherent in the natural endowments but its competitiveness depends on its innovativeness (Porter, 1998). According to the World Economic Forum Competitiveness Index ranking, Zimbabwe has been faring badly, an observation corroborated by a general consciousness on the part of respondents that Zimbabwe has many issues that need redress for competitiveness. As confirmed by the hypothesis test, Zimbabwe is not a competitive country as an investment or tourist destination compared to its counterparts. On the investment front, the Government of Zimbabwe should advance the initiative adopted on implementing the ease of doing business reforms to attract both domestic and foreign investment. The macro environment should be configured to protect private enterprise and bilateral trade and investment agreements. The tourism players and the industry should work on addressing their product quality and pricing. According to the World Economic Forum's 2015/16 Global Competitiveness Report, the most problematic factors for doing business include policy instability, inadequate foreign currency regulations, inefficient government bureaucracy, difficulties in access to finance, inadequate supply of infrastructure, restrictive labour regulations, and inefficient tax administration and regulations.

Global Risk Factors Facing Zimbabwe: An analysis of what were perceived to be global risks facing Brand Zimbabwe was done. The global risk factors were categorised under social, economic, environmental (ecological), geopolitical and technological. 
Social Risk Factors: The social risk factors examined included the threat of an ageing population; failure of urban planning; food shortages and crises; large-scale involuntary migration; social instability; the spread of infectious diseases; water crises; increasing national sentiment; poverty; and crime. The respondents were asked to indicate their opinion of Brand Zimbabwe against the risk factors. Overall, the respondents concurred that the country faced a handful of social risk factors. The most significant social risk factors facing the country based on perceptual scores were threat of failure of urban planning (75.4\%); poverty (71\%); large-scale involuntary migration (70.7\%); water crises (66.4\%); social instability (61.6\%); food crises (61\%); and increasing national sentiment (58.8\%) in that order, respectively. The least threatening social risks were, the threat of the spread of infectious diseases (34.9\%); crime (35\%); and followed by the threat of an ageing population (35.5\%). The statistics above indicate a plethora of social risk drivers facing the nation brand which is a cause for concern (for it threatens tourists and investors alike and affects the country of origin effect for the country's exports).

Economic Risk Factors: An examination of the economic factors facing the country included commodity prices; energy price shocks; failure of financial systems; failure of critical infrastructure; fiscal crises; unemployment or underemployment; and currency volatility. The statistical findings revealed that all the economic risk factors were perceived to pose threats for Brand Zimbabwe. The most impacting risk against the country was the incidence of structural unemployment and underemployment with a score of $81 \%$; followed by currency risk (80\%); fiscal crises (78.8\%); higher commodity prices (78.4\%); failure of financial systems (75.2\%); failure of critical support infrastructure (66.7\%); and lastly price shocks that are induced by energy problems (66\%). The macroeconomic environment was seen to be a source of threat against the nation brand's equity as they affect the cost and standard of living, the cost of doing business, the competitiveness of the country's exports.

Environmental and Ecological Risk Factors: An examination of the ecological and physical environmental risks facing Zimbabwe was also done. The ecological factors examined were extreme weather conditions; adaptation to climatic changes; biodiversity loss; and the collapse of the natural ecosystem. The majority of the respondents (61\%) disagreed that extreme weather events like floods are a risk facing the nation branding as an international destination. Approximately 35\% of the respondents agreed that biodiversity loss and collapse of the natural ecosystem are risk factors impacting Zimbabwe. The results however, suggest that Zimbabwe is viewed as marginally faced with risk from extreme weather conditions.

Geo-Political Risk Factors: The research also assessed geo-political factors around Brand Zimbabwe. The factors examined were inter-alia, failure of national governance (corruption, and organised crime); failure in the rule of law and property rights; and large-scale terrorism; state collapse (civil conflict, military coup, and failed states). The research established that the failure of national governance (e.g. corruption, organized crime, etc.) was a major risk factor (86\%) facing Brand Zimbabwe. The research also suggests that failure in the rule of law and property rights was also observed as a geopolitical risk factor affecting the national brand with a frequency of $79 \%$. The threat of civil conflict, a military coup and failed state was regarded as a potential threat by a frequency of $65 \%$. The results could have been influenced by the country's history of political violence, contested elections, the fall of former President Mugabe's administration, the unresolved cases of corruption and politically-induced loss of property.

The importance of perceived risk is underscored for consumer brand decision making (Kapferer, 2008). The research established that Brand Zimbabwe was perceived to be exposed to various threats inclusive of political volatility, economic instability, foreign exchange shortages and volatile exchange rates, currency volatility and cash risk, threats to property rights and expropriation. It was also observed that the country is also exposed to the problem of unattractive ease of doing business environment and policy and legislative mishmash. The country was observed to lack legislative and policy consistency giving rise to the need to harmonise the legislation and policy environment, uphold property rights and bilateral and multilateral agreements, the rule of law among other things to avoid scaring investors. Discord in government and policy administration has a detrimental effect on stakeholder confidence particularly foreign visitors and investors. 
Technological Risk Factors: An interrogation of the technological environment was undertaken for Brand Zimbabwe. The respondents expressed their perception of the country with regards to large-scale cyberattacks; the incident of data theft; abuse of technologies (social media, and piracy); and breakdown of information infrastructure. The results suggest that Zimbabwe was less risky with regards to large-scale terrorism; large-scale cyber-attacks and large incidents of data fraud. The incidence of data fraud or theft was considered a minor technological risk factor affecting the nation by close to $40 \%$ of the respondents. The statistics indicate that there are significant technologically-driven risk drivers facing the nation brand around the abuse of technology. The abuse of technologies such as social media and piracy was considered high impact risk factors affecting the nation with a score of $72 \%$.

The research also assessed the nation brand on the basis of globally identified risk factors that influence global behaviour. The global risk factors were classified as social, economic, environmental, geopolitical and technological. The research findings show that the major social risk factors facing the country were poverty (51\%) and water crises (50\%). The economic risk factors impacting the nation brand were largely on high prices for commodities slightly above (59\%). Biodiversity loss and ecosystem collapse were also among the identified risk factors by $35 \%$ of the respondents. On geopolitical factors, failure of national governance was cited as a high-risk factor for the nation brand by $45 \%$ of the respondents. The findings however suggest that Zimbabwe has low-risk exposure with regards to large-scale terrorism, state collapse or crisis, large-scale cyber-attacks and large incidents of data fraud. As such, technological factors were not considered as a major threat for the country.

Research has highlighted that perceived risks that crowd and impact on consumer's decision were economic and social risks linked to people's social image (Kapferer, 2008). Hence it is very important to build brand saliency at brand awareness stage and trust in the beliefs of brand image. The statistical findings were a mere confirmation of the elongated macroeconomic challenges facing the country for nearly 20 years. The country experienced periods of haemorrhaging inflation and negative returns from investment and that saw company closing down, consumers losing their savings in the face on massive bank closures and currency reforms. Essentially the research findings suggest overwhelmingly that Zimbabwe is a high-risk country based on a number of social, economic, environmental, geopolitical, and technological factors.

\section{Results of Hypothesis Test}

Hypothesis 1: Zimbabwe is not a competitive country based on identified competitiveness and differentiating indicators. Following the statistical observations on Zimbabwe's competitive and differentiating indicators, a correlation analysis was conducted to test the above hypothesis. The broad factors were drawn from economic, social, governance and physical domains. Table 1 shows the correlation matrix.

Table 1: Correlation Matrix on Competitiveness of Zimbabwe

\begin{tabular}{|c|c|c|c|c|c|c|c|c|c|c|c|c|c|c|c|c|c|c|}
\hline & & 1 & 2 & 3 & 4 & 5 & 6 & 7 & 8 & 9 & 10 & 11 & 12 & 13 & 14 & 15 & 16 & 17 \\
\hline \multirow{14}{*}{$\begin{array}{l}0 \\
0 \\
\frac{\pi}{0} \\
0 \\
0 \\
0\end{array}$} & SQ21 & 1.00 & 0.42 & 0.52 & 0.44 & 0.15 & 0.26 & 0.00 & 0.29 & 0.32 & 0.33 & 0.27 & 0.36 & 0.04 & 0.34 & 0.33 & 0.14 & 0.00 \\
\hline & SQ22 & & 1.0 & 0.47 & 0.41 & 0.22 & 0.32 & 0.12 & 0.31 & 0.35 & 0.29 & 0.50 & 0.41 & 0.13 & 0.33 & 0.30 & 0.17 & 0.05 \\
\hline & SQ23 & & & 1.00 & 0.47 & 0.07 & 0.30 & 0.01 & 0.41 & 0.38 & 0.28 & 0.40 & 0.40 & 0.03 & 0.45 & 0.34 & 0.21 & 0.03 \\
\hline & SQ24 & & & & 1.00 & 0.14 & 0.32 & 0.04 & 0.36 & 0.28 & 0.36 & 0.41 & 0.38 & 0.03 & 0.34 & 0.35 & 0.20 & 0.06 \\
\hline & SQ25 & & & & & 1.00 & 0.26 & 0.41 & 0.23 & 0.14 & 0.33 & 0.27 & 0.08 & 0.27 & 0.00 & 0.08 & 0.01 & 0.07 \\
\hline & SQ26 & & & & & & 1.00 & 0.28 & 0.42 & 0.34 & 0.35 & 0.44 & 0.25 & 0.16 & 0.37 & 0.27 & 0.24 & 0.04 \\
\hline & SQ27 & & & & & & & 1.00 & 0.22 & 0.05 & 0.24 & 0.18 & 0.03 & 0.32 & 0.02 & 0.03 & 0.03 & 0.13 \\
\hline & SQ28 & & & & & & & & 1.00 & 0.41 & 0.28 & 0.44 & 0.38 & 0.07 & 0.33 & 0.35 & 0.26 & 0.00 \\
\hline & $\begin{array}{l}\text { SQ29 } \\
\text { SQ210 }\end{array}$ & & & & & & & & & 1.00 & $\begin{array}{l}0.35 \\
1.00\end{array}$ & $\begin{array}{l}0.39 \\
0.41\end{array}$ & $\begin{array}{l}0.36 \\
.2 .4\end{array}$ & $\begin{array}{l}0.04 \\
0.15\end{array}$ & $\begin{array}{l}0.31 \\
0.22\end{array}$ & $\begin{array}{l}0.31 \\
0.21\end{array}$ & $\begin{array}{l}0.22 \\
0.19\end{array}$ & $\begin{array}{l}-0.07 \\
0.05\end{array}$ \\
\hline & $\begin{array}{l}\text { SQ211 } \\
\text { SQ212 }\end{array}$ & & & & & & & & & & & 1.00 & $\begin{array}{l}0.48 \\
1.00\end{array}$ & $\begin{array}{l}0.04 \\
0.02\end{array}$ & $\begin{array}{l}0.41 \\
0.39\end{array}$ & $\begin{array}{l}0.30 \\
0.28\end{array}$ & $\begin{array}{l}0.33 \\
0.24\end{array}$ & $\begin{array}{l}0.01 \\
0.05\end{array}$ \\
\hline & $\begin{array}{l}\text { SQ213 } \\
\text { SQ214 }\end{array}$ & & & & & & & & & & & & & 1.00 & $\begin{array}{l}0.02 \\
1.00\end{array}$ & $\begin{array}{l}0.01 \\
0.57\end{array}$ & $\begin{array}{l}0.04 \\
0.39\end{array}$ & $\begin{array}{l}0.31 \\
0.02\end{array}$ \\
\hline & SQ215 & & & & & & & & & & & & & & & 1.00 & 0.51 & 0.04 \\
\hline & SQ216 & & & & & & & & & & & & & & & & 1.00 & 0.08 \\
\hline & SQ217 & & & & & & & & & & & & & & & & & 1.00 \\
\hline
\end{tabular}


Key:

SQ: Survey questionnaire component (2.1)

2: Physical infrastructure

4: Health systems

6: Product and service market efficiency

8: Financial market efficiency

10: Market size

12: Factor prices

14: Cost of doing business

16: Stable currency
1: Public institutions

3: Macroeconomic environment

5: Education systems

7: Labour skills and market efficiency

9: New technology adoption

11: Facilities and services

13: Natural resources

15: Political stability

17: Geographical location

Source: Calculated from Survey Results (based on the Global Competitiveness Report by WEF)

The correlation matrix, Table 1, shows the correction factors, which potentially influence nation branding for Zimbabwe. All factors with correlations with values $\mathrm{p}<0.05$ had a significant relationship. Essentially, physical infrastructure, macroeconomics, health systems, labour market and skills, financial market efficiencies, technology adoption, public facilities and services, factor prices and cost of production, cost of doing business and currency instability were identified as major negative issues affecting the brand. The factors had significant correlations between the observed and latent scores. Correlations that range from 0 to 0.4 are weak, 0.4 to 0.7 are moderate while those correlation coefficients $p>0.7$ greater are strong (Jolliffe, 2011). Table 2 below shows the rotated component matrix on the competitiveness of Zimbabwe based on the same competitiveness and differentiating factors.

Table 2: Rotated Component Matrix on Competitiveness of Zimbabwe

\section{Rotated Component Matrix ${ }^{a}$}

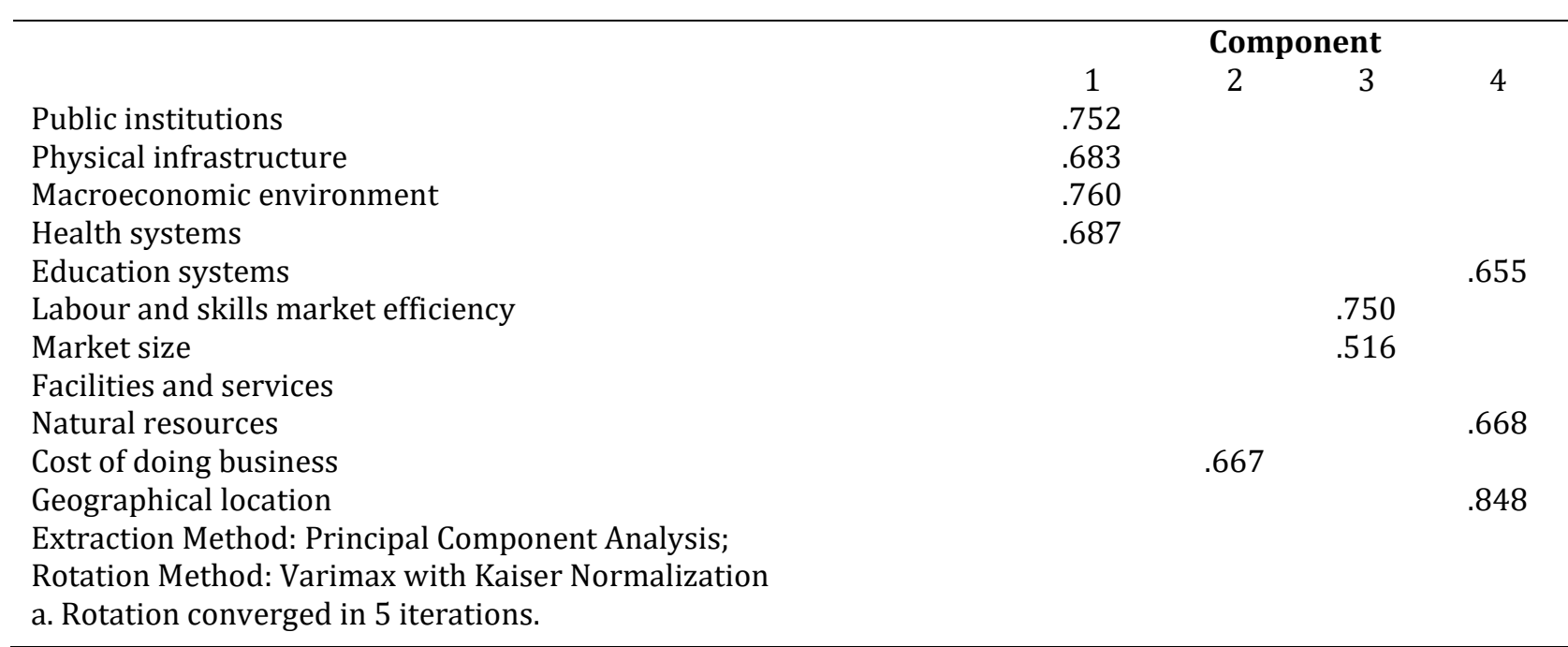

Source: Calculated from Survey Results

The component matrix (Table 2) confirms that Brand Zimbabwe is not competitive because of a number of negative perceptions on the identified competitive and differentiating factors. Four principal factors are present with factor 1 (negative) consisting of economic and physical infrastructure factors, while component 2 is about doing business, component 3 is market factors and component 4 (positive) is composed of ecological factors. Based on the rotated component matrix above, the four factors extracted suggest that Zimbabwe was perceived as uncompetitive on a number of competitiveness and differentiating indicators. The nation brand however, enjoys equity from environmental factors and education in component 4, perceived positively, and followed by labour and skills market efficiency and product market size. All other factors 1 and 2 namely health systems, public institutions, macroeconomics, physical infrastructure and cost of doing business were significantly negative rendering the nation brand rather uncompetitive. 


\begin{tabular}{l} 
Journal of Economics and Behavioral Studies (ISSN: 2220-6140) \\
Vol. 10, No. 6, pp. 99-112, December 2018 \\
\hline \hline
\end{tabular}

Hypothesis 2: Zimbabwe is a high-risk country based on social, economic, environmental, geopolitical, and technological factors. There was a general consciousness on the part of respondents that Zimbabwe has many issues that should be addressed to be competitive on the global market. Factor analysis was conducted on the data to test the above hypothesis so as to extract the principal factors with statistical significance. The findings are in Table 3 below.

Table 3: Rotated Component Matrix: Zimbabwe is a High-Risk Country Rotated Component Matrix ${ }^{a}$

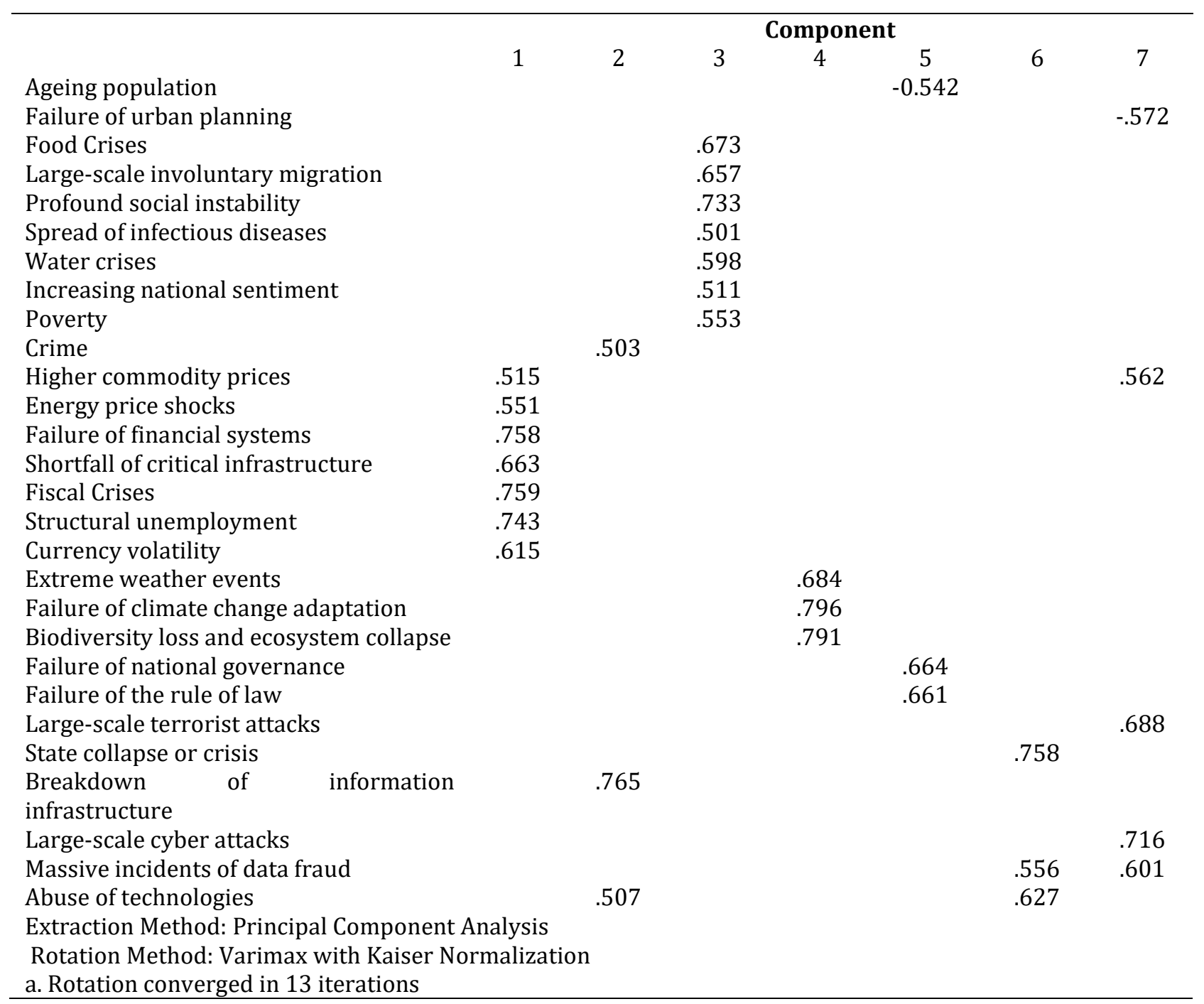

Source: Calculated from survey results (based on the Global Risks Report by WEF)

The calculated research results illustrate that Zimbabwe is a high-risk country based on social, economic, environmental, geopolitical and technological factors. Seven components were extracted and component 1 being the most influential risk and component seven being the least. Social and economic factors constituted component 1 and included issues of fiscal policy and activity, high prices, currency volatility and lack infrastructural development and maintenance. These placed Zimbabwe at risk the most, followed by those in Component 2, mainly technological abuse, crime and breakdown in infrastructure. Security issues, vulnerability to cyber-attacks, threats to terrorist attacks, state collapse and crisis and large cases of data fraud were minimal. Component 3 of the matrix comprise a mix of critical issues that affect the nation brand from a social perspective including the threat of spread of infectious diseases, food crises, large-scale emigration, water crisis and increasing national sentiment. 
Zimbabwe was viewed to be at the risk of failure to adapt to climate change and extreme weather conditions, which threaten biodiversity and ecosystem collapse. The issue of risk around governance encompassing the rule of law and intellectual and property rights was also evident. One can easily conclude that Zimbabwe has a high-country risk profile based on social, economic, environmental, geopolitical, and technological factors. The quantitative research findings on the risk profile of the country were validated by the depth interview findings from the local key informants and foreign respondents. One is however, convinced that the sources of risk are predominantly issues that can be resolved if the country is sincere in its nation rebranding mantra.

Brand Zimbabwe's Impact on FDI Performance: Key informants were convinced that Zimbabwe was punching below her weight for far too long. They were positive that the poor foreign direct investment (FDI) performance by the country was a direct consequence of how the nation brand was perceived by foreign investors. Zimbabwe attracted low FDI compared to her regional counterparts over time which signals a positive relationship between nation brand image and FDI performance consistent with (Sikwila, 2015) and (Kalamova \& Konrad, 2010). Nations naturally have to compete for the scarce foreign direct investment which heightens the need for nations to craft strategies to attract a reasonable share of global FDI. Countries pursuing FDI are reminded that their policymakers should realise that they compete with a lot of other nations with similar characteristics (Smallbone, 2008). Policymakers therefore should comprehend how national policy affects perceptions and behaviour towards the national brand. Policies that threaten the image and reputation of a country should be monitored and managed to minimise the overall impact on the country's investment performance. They are largely issues springing from of a governance perspective thus nation branding effort for Zimbabwe should be anchored by the governance pillar of the nation.

The research findings suggest that whilst investment from the traditional source markets (EU and America) plummeted, Chinese investment was however on the rise. Could this paradox be explained in the context of change in government policy after the R.G Mugabe administration's 'Look East Policy' or a function of the different risk appetite of the investors coming from the two different source markets? The observation was that government and investment policies were friendly to the East and assured investors from that region security and investment protection whilst harsh for investors from elsewhere. The research established that investors were extremely careful before making decisions on Zimbabwe. It was suggested that some of the positives drawing investor interest to Zimbabwe included the country's natural resources, a well-educated workforce, friendly and loyal population, fast-growing regional economies and great long-term overall potential. Zimbabwe's negativities were largely governance and economic issues as substantiated by the local key informants. The major issues included heavy state involvement in private business, government expenditure and recurrent budget deficit, uncertainty regarding repatriation of earnings, private property rights and threat to the rule of law, currency and cash crisis, deteriorated infrastructure, exchange rates and foreign currency shortages, among other issues. The research established that the country performed poorly against its global counterparts with regards issues around the ease of doing business. These factors included basics such as availability of information, company registration, administrative requirements, infrastructure, and utilities to the cost of doing business. The research identified the following as key ease of doing business factors requiring attention:

- Stability and security of investment

- Investors are attracted by easy, quick start-up procedures; no unnecessary hassle

- Harmonised local and central government regulations

- No excessive labour regulations

- Availability of well-educated personnel with modest salary expectations

- Easy monetary system - easy foreign payments to / from abroad

- Manageable in- and export regulations

- Availability and easy access to information and investment service touch-points

The raised issues are subjects under review of the ease of doing business reforms championed by the office of the president. The country is in the process of enhancing the investment environment through the Special Economic Zones (SEZs) investment model. The Zimbabwe Investment Authority was created to create a onestop shop investment service Centre for FDI. All that the country requires is full operationalisation of her 
noble and great intentions to build equity for the national brand. Theory propositions on foreign investment points to different reasons for international flow of capital, thus, the resource market and efficiency seeking objectives. Whilst the research suggests a positive opinion of Zimbabwe's standing on resource endowments, the country was seen to be performing badly on market efficiency and market availability arising from a distorted currency regime and poor economic performance.

Brand Zimbabwe and Tourism Performance: The research established that the Ministry of Tourism and Hospitality of Zimbabwe put up a solitary fight to promote the image of the country. Some respondents observed that hosting international conferences and events such as the UNWTO 2015 were essential for the promotion of positive word of mouth for the national brand. The tourism visitation from 2008 to 2017 performed reasonably well compared against how the nation brand was projected by the international media. There are factors to explain this trend. It was highlighted that visitation to such places as the Victoria Falls and nearby game parks were as a result of foreign promotion by South Africa or Zambia. Thus, the numbers that visit the country are not a direct reflection of the power of the national brand. To fully leverage the tourism products from the country, Zimbabwe should formulate a holistic nation branding strategy, deal with a host of the nation brand negatives and consciously recover the lost nation brand equity. Foreign visitors raised concern with regard to holiday travel to Zimbabwe. They advised that Zimbabwe was perceived as weak on tourism goods and services namely unattractive hotels, restaurants and shops and also a negatively perceived security problem. In a global village with competing countries, the implication of these findings is that the attractiveness of Zimbabwe is compromised.

Views on Country of Origin Effect on Zimbabwean Exports: The research established that export performance for the country over the period was largely below the country's capacity. There were issues around export competitiveness, product quality and negative country of origin (COO) effect. Whilst some believed that the country produced very good quality products, the product portfolio predominantly comprised primary or semi-processed products. The country falls short in matching world quality standards and suffers from the high cost of production aggravated by the use of the strong currency (US Dollar), constraints in capacity utilisation and outmoded machinery. It must be understood that local manufacturers and exporters are the drivers of the exports for the nation brand (Chitty, et al., 2016). If the manufacturers are not competitive on quality, pricing and other conditions, the country performs badly. Perception of COO is however, very negative for Zimbabwean products particularly to markets outside Africa. Retooling was highlighted as a major strategic issue requiring attention to enhance the country's export competitiveness assuming that the negative $\mathrm{COO}$ effect on exports is attended. Consistent with findings from researches which observed, that the Germany nation brand is such a fundamental cog in the development and growth of exports arising from a positive 'made-in-Germany-effect' (Joseph, 2016).

\section{Concluding Remarks}

The research concludes that nation branding for Zimbabwe is such a strategic imperative requiring immediate attention to improve the fortunes of the country. Brand Zimbabwe is negatively viewed owing to myriad risk factors that require a holistic and sincere approach from the policymakers. The threats to the viability of Brand Zimbabwe were largely of a political and governance origin with a ripple effect on the economics and social space of the country. There is a general consensus that the country's investment attraction, visitation and export promotion cannot be resolved if the country's image question remains unresolved. The new administration led by President E.D. Mnangagwa realised the need to restore the country's relationship with the international community hence the mantra that 'Zimbabwe is now open for business. This is the first step in the right direction. What is required to restore the nation brand lustre is to decisively act on addressing the threats identified by the research. The nation's performance at the global market is largely a function of the nation brand's attractiveness and image as perceived by its visitors, investors and buyers. 


\section{References}

Abimbola, T. (2010). Brand strategy as a paradigm for marketing competitiveness. Journal of Brand Management, 18(1), 177-179.

Alvarez, M. D. \& Campo, S. (2014). The influence of political conflicts on nation image and intention to visit: A study of Israel's image. Tourism Management, 70-78.

Anglade, L. (2018). What Difference do the Government Institutions of Haiti and the Government Institutions of the Dominican Republic Make for Tourism Growth? Georgia: Georgia State University.

Anholt, S. (2007a). Competitive identity: the new brand management for nations, cities and regions. London: Palgrave, Macmillan.

Anholt, S. (2010). Places: identity, image and reputation. London: Palgrave, Macmillan.

Avraham, E. (2018). Nation branding and marketing strategies for combatting tourism crises and stereotypes toward destinations. Journal of Business Research, 36(2), 1-10.

Bolin, G. \& Miazhevich, G. (2018). The soft power of commercialised nationalist symbols: Using media analysis to understand nation branding campaigns. European Journal of Cultural Studies, 16(1), 3-21.

Bregoli, I. (2016). Towards a theoretical framework on Internal Destination Brand Strength. UK, University of Lincoln Business School.

Chitty, N., Ji, L., Rawnsley, G. \& Hayden, C. (2016). The Routledge Handbook of Soft Power. s.l.: Taylor \& Francis, Routledge International Handbooks.

Cochran, W. (1977). The estimation of sample size. Sampling Techniques, 1(3), 72-90.

De Chernatony, L. (2006). From Brand Vision to Brand Evaluation: The Strategic Process of Growing and Strengthening Brands. s.l.: Net Library, Inc., Elsevier.

Dinnie, K. (2008a). Japan's national branding: Recent evolution and potential paths. Journal of current Japanese affairs, 14(1), 152-175.

Dinnie, K. (2015). Nation Branding: Concepts, issues, practice. s.l. Routledge.

Dinnie, K., Melewar, T., Seidenfuss, K. \& Musa, G. (2010). Nation branding and integrated marketing communications: an ASEAN perspective. International marketing review, 27(4), 388-403.

Gilmore, F. (2002). A country-Can it be repositioned? Spain-The success story of country branding. Journal of Brand Management, 9(4), 281-293.

Gumpo, S. (2005). Branding a country: the case of Zimbabwe, RSA: University of South Africa.

Haig, M. (2005). Brand failures: the truth about the 100 biggest branding mistakes of all time. s.l.: Kogan Page Publishers.

Ih-Prost, O. \& Bondaz, A. (2014). South Korea is trying to improve its nation brand, Paris: Asia Centre.

Jaffe, E. (2015). A Review of "Place Images and Nation Branding in the African Context: Challenges, Opportunities, and Questions for Policy and Research. Africa Journal of Management, 1(3), 284-294.

Jaffe, E. \& Nebenzahl, I. (2001). National image and competitive advantage: the theory and practice of nationof-origin effect. Copenhagen, Copenhagen Business School Press.

Jolliffe, I. (2011). Principal component analysis. In International encyclopaedia of statistical science, 10941096.

Joseph, U. (2016). The 'Made in Germany' Champion Brands: Nation Branding, Innovation and World Export Leadership, s.l.: Routledge.

Kalamova, M. \& Konrad, K. (2010). Nation brands and foreign direct investment, Berlin: The Social Science Research Centre.

Kapferer, J. (2008). New strategic brand management. London: Kogan Page Limited.

Kato, S. (2002). A study of research methods, faculty of business administration, Tokyo: Bunkyo Gakuin University.

Kemming, J. (2009). Nation brand management in political contexts: Public diplomacy for Turkey's European Union accession, Istanbul: Universität Giessen.

Klaus, S. (2016). The Global Competitiveness Report 2015-2016, Geneva: World Economic Forum.

Konecnik, M. \& Go, F. (2008). Tourism destination brand identity: The case of Slovenia. Journal of Brand Management, 15(3), 177-189.

Lee, K. (2009). Nation branding and sustainable competitiveness of nations, The Netherlands: University of Twente.

Ludmilla, A. (2018). What Difference do the Government Institutions of Haiti and the Government Institutions of the Dominican Republic Make for Tourism Growth? Georgia: Georgia State University. 


\section{Journal of Economics and Behavioral Studies (ISSN: 2220-6140)}

Vol. 10, No. 6, pp. 99-112, December 2018

Nimijean, R. (2018). Introduction: Is Canada back? Brand Canada in a turbulent world. Canadian Foreign Policy Journal, 24(2), 127-138.

Olins, W. (2013). Nation branding. Graz, UNESCO City of Design.

Porter, M. (1998). Clusters and the new economics of competition. Harvard Business Review, 76(1), 77-90.

Quelch, J. \& Jocz, K. (2009). Can brand Obama rescue brand America? Brown journal of world affairs, 16(1), 163-178.

RBZ. (2016). Bank Supervision Annual Report, Harare: Reserve Bank of Zimbabwe.

Reibstein, D. (2017). Improving Economic Prosperity through Nation Branding the Marketing Journal.

Rolfe, G. (2006). Validity, trustworthiness and rigour: quality and the idea of qualitative research, United States National Library of Medicine.

Schmitt, T. \& Sass, D. (2011). Rotation criteria and hypothesis testing for exploratory factor analysis: Implications for factor pattern loadings and interfactor correlations. Educational and Psychological Measurement, 71(1), 95-113.

Sikwila, M. (2015). Foreign direct investment: does it matter? A case for Zimbabwe. Research in business and economics journal, 11(2), 34-52.

Skinner, H. \& Kubacki, K. (2007). Unravelling the complex relationship between nationhood, national and cultural identity, and place branding. Place Branding and Public Diplomacy, 3(4), 305-316.

Smallbone, D. (2008). Foreign direct investment and small to medium enterprise development: Some policy issues for transition and developing nations, Kingston: Kingston University, Small Business Research Centre.

Sorrel, M. (2014). Nation Branding and Global Politics: A Conversation with Sir Martin Sorrell.

Spio, A., Frimpong, K. \& Austin, N. (2011). Country branding: a developing economy perspective. International Journal of Business Strategy, 11(2), 123.

Sudman, S., Greeley, A. \& Pinto, L. (1965). The effectiveness of self-administered questionnaires. Journal of Marketing Research, 1(1), 293-297.

Tecmen, A. (2018). The relations between public diplomacy and nation brands: an investigation of nation branding in Turkey, Istanbul: European Institute, Istanbul Bilgi University.

Wharton. (2016). Nation Branding: Perception Can Be Reality — So Manage It'.

Zeineddine, C. (2017). Employing nation branding in the Middle East - United Arab Emirates (UAE) and Qatar. Management \& Marketing. Challenges for the Knowledge Society, 12(2), 208-221. 